\title{
Luteolin absorption in Rhizobium meliloti wild-type and mutant strains
}

\author{
C. Hubac, ${ }^{1 *}$ J. Ferran, ${ }^{1}$ D. Guerrier, ${ }^{1}$ A. Trémolières ${ }^{2}$ and A. Kondorosi ${ }^{1,3}$ \\ ${ }^{1}$ Institut des Sciences Végétales and ${ }^{2}$ Laboratoire de Biochimie Fonctionnelle des Membranes Végétales, CNRS, \\ 91198 Gif-sur-Yvette Cedex, France \\ ${ }^{3}$ Institute of Genetics, Biological Research Centre, Hungarian Academy of Sciences, 6701 Szeged, Hungary
}

(Received 14 October 1992; revised 26 January 1993; accepted 17 February 1993)

\begin{abstract}
Luteolin is a flavonoid produced by plants which is required for induction of nod genes in Rhizobium meliloti. $R$. meliloti absorbed luteolin at higher rate than all other bacteria tested, including $R$. leguminosarum. The flavonoids naringenin and quercetin, which do not induce the expression of nodulation genes of $R$. meliloti, were absorbed at a lower rate by this species, suggesting a certain degree of species specificity of flavonoid absorption. Luteolin accumulated preferentially in the outer membrane, but a small amount was always found in the inner membrane. Luteolin strongly inhibited NADH oxidase, an enzyme of the respiratory chain, raising the possibility that the site of luteolin absorption in the outer membrane allows the protection of the respiratory chain located in the inner membrane from an excess of flavonoids. The incorporation of luteolin was found to be affected in some exo or nod mutants of $R$. meliloti. The exoB mutant, which does not produce exopolysaccharides, accumulated lower amounts of luteolin in the outer membrane than the $\mathrm{exo}^{+}$parent. Among the nod mutants affected in nodulation genes, those not expressing any of the three nodD genes accumulated luteolin at a significantly lower level in both the outer and the inner membrane. A strain overexpressing the nod genes, particularly the nodD genes, absorbed luteolin at a higher level in both membranes. These results indicate that absorption of luteolin by $R$. meliloti involves several gene products, including the NodD protein.
\end{abstract}

\section{Introduction}

In rhizobia the expression of nodulation (nod) genes is induced by the regulatory NodD protein in conjunction with flavonoids produced by the host plants (for a review see Kondorosi, 1992). In general, the nodD genes are expressed constitutively, and genetic data indicate that upon binding of the flavonoids to the NodD proteins the activated NodD can induce the expression of the nod genes. However, the specific binding of flavonoids to the NodD proteins has not yet been directly demonstrated.

The specific interaction between flavonoids of the host plant and NodD ensures the host-specific control of nod gene expression. For example, luteolin $\left(3^{\prime}, 4^{\prime}, 5,7\right.$-tetrahydroxyflavone) isolated from Medicago sativa seed extracts was shown to be a potent nod gene inducer in Rhizobium meliloti (Peters et al., 1986), while naringenin (5,7,4'-trihydroxyflavanone) isolated from Vicia sativa root exudate is an important nod gene inducer in Rhizobium leguminosarum biovar viciae (Zaat et al.,

$\begin{array}{lllll}\text { *Author for correspondence. } & \text { Tel } 169823603 ; & \text { fax } \\ 169823695 \text {. } & & & & \end{array}$

1988). This latter compound was shown to have no nod gene inducing ability in $R$. meliloti (Györgypal et al., 1991 a). Isoflavonoids were found to be potent nod gene inducers in Bradyrhizobium but had no inducing activity in most Rhizobium species, or even inhibited induction of nod genes (for a review see Györgypal et al., 1991a).

Using antibodies against a lac $Z$-nodD gene fusion product, Schlaman et al. (1989) found that the NodD protein is located exclusively in the cytoplasmic membrane of wild-type $R$. leguminosarum biovar viciae cells. In a $R$. leguminosarum strain overproducing NodD, the protein was found both in the cytoplasmic membrane and in the cytosol, indicating an influence of the protein abundance on its subcellular localization. A model for nod gene induction was presented which combines the localization and the DNA-binding properties of the NodD protein as well as the observed association of flavonoids with the cytoplasmic membrane.

The accumulation of naringenin in the cytoplasmic membrane of $R$. leguminosarum biovar viciae, without apparent metabolic conversion, was reported by Recourt et al. (1989). The binding of naringenin was highly reversible and in vitro experiments showed that narin- 
Table 1. Genetic and symbiotic characteristics of strains used in this study

\begin{tabular}{|c|c|c|c|}
\hline $\begin{array}{l}\text { Strains } \\
\text { and plasmids }\end{array}$ & Relevant genotype & $\begin{array}{l}\text { Symbiotic } \\
\text { phenotype }\end{array}$ & Reference/source \\
\hline \multicolumn{4}{|l|}{ R. meliloti } \\
\hline Rm41 & & $\mathrm{Nod}^{+} \mathrm{Fix}^{+}$ & Original isolate by K. Szende \& F. Ordögh \\
\hline AK631 & $\mathrm{Rm} 41$ exoB & $\operatorname{Nod}^{+} \mathrm{Fix}^{+}$ & Kondorosi et al. (1989) \\
\hline EK698 & AK631 nolR::Tn5 & Nod $^{+*} \mathrm{Fix}^{+}$ & Kondorosi et al. (1989) \\
\hline EK1261 & EK698(pEK327) & & Obtained from E. Kondorosi \\
\hline $\mathrm{Rm} 1021$ & nolR & Nod $^{+*} \mathrm{Fix}^{+}$ & Meade et al. (1982) \\
\hline AK 1672 & AK631nodC:: $\operatorname{Tn} 5$ & $\mathrm{Nod}^{-}$ & Kondorosi et al. (1984) \\
\hline ZB138 & $\begin{array}{l}\text { nod-nif deletion derivative } \\
\text { of AK631 }\end{array}$ & $\mathrm{Nod}^{-}$ & Banfalvi et al. (1981) \\
\hline A2105 & $\begin{array}{l}\mathrm{Rm} 1021 \text { nodC-lacZ } \\
\text { nodD1D2D3 }\end{array}$ & $\mathrm{Nod}^{-}$ & Honma et al. (1990) \\
\hline \multicolumn{4}{|l|}{ Plasmid } \\
\hline pEK327 & $\begin{array}{l}\text { pLAFRI carrying } \\
\text { nodFEGHPQD3 and } s y r M\end{array}$ & & Schultze et al. (1992) \\
\hline R. leguminosarum 248 & Wild-type strain & $\mathrm{Nod}^{+} \mathrm{Fix}^{+}$ & Josey et al. (1979) \\
\hline A. tumefaciens 82139 & Wild-type strain & & Michel et al. (1990) \\
\hline A. rhizogenes A4TC24 & $\mathrm{C} 58 \mathrm{Cl}$ & & Petit et al. (1983) \\
\hline P. syringae pv. pisi & Wild-type strain & & Schmit (1991) \\
\hline E. coli $\mathrm{K} 12$ & $\mathrm{C} 600$ & & Appleyard (1954) \\
\hline
\end{tabular}

* About $2 \mathrm{~d}$ delay in nodulation.

genin had a high, $\mathrm{pH}$-dependent affinity for the cytoplasmic membrane.

The flavonoids may have effects on rhizobia other than nod gene induction. The growth rate of $R$. meliloti was enhanced by flavonoids released naturally from $M$. sativa seeds, but only in a minimal medium that allowed rather poor growth and not in the presence of yeast extract and tryptone (Hartwig et al., 1991). It was suggested that the mechanism which increases growth is distinct from its capacity to induce rhizobial nod genes and that luteolin may create ecochemical zones for controlling soil microbes.

We have undertaken a more extensive study of the mechanisms involved in luteolin absorption by $R$. meliloti. As a first step, we studied how luteolin was absorbed by $R$. meliloti and $R$. leguminosarum and by other Gram-negative bacteria, including Agrobacterium tumefaciens, A. rhizogenes, Pseudomonas syringae and Escherichia coli. In addition, absorption of two flavones not inducing the nod genes in $R$. meliloti, namely naringenin and quercetin, was investigated. By incubating live bacteria with luteolin, the amount of flavonoid absorbed in the inner and outer membranes of wild-type and mutant strains affected in the nod region was determined.

\section{Methods}

Bacterial strains and plasmids. These are listed in Table 1.

Media and culture conditions. Liquid cultures were grown at $30^{\circ} \mathrm{C}$ with aeration on different media for each bacterium: TA medium
(Tryptone-yeast) (Kondorosi et al., 1977) for R. meliloti and E. coli, TY medium (Beringer, 1974) for $R$. leguminosarum, YEB medium (AltMoerbe et al., 1989) for Agrobacterium, YAD medium (Meng \& Wang, $1987)$ for $P$. syringae. Growth of bacteria was followed spectrophotometrically by measuring the optical density at $540 \mathrm{~nm}$. Samples were taken during the exponential phase of growth $\left(\mathrm{OD}_{540}=0.9\right)$.

Fractionation of membranes. Overnight bacterial cultures were harvested by centrifugation at $5000 \mathrm{~g}$ for $30 \mathrm{~min}$ at $4{ }^{\circ} \mathrm{C}$, washed twice in $0.9 \% \mathrm{NaCl}$. The cells were broken by two passages through a French press cell (about $70 \mathrm{MPa}$ ). Membranes were fractionated on a discontinuous sucrose density gradient (Hubac et al., 1992). The protein content of different fractions of the gradient was determined by the method of Bradford (1976). Two membrane markers, the KDO (2ketodeoxyoctonate) content for the outer membrane and the NADH oxidase activity for the inner membrane (de Maagd \& Lugtenberg, 1986), were used. By following the profile of the protein content, the outer membrane was found in the $55 \%(\mathrm{w} / \mathrm{v})$ sucrose fractions, and the inner membrane in the $35 \%$ sucrose fractions (Hubac et al., 1992).

$N A D H$ oxidase activity measurement. The pellet containing the membranes was suspended in $50 \mathrm{~mm}-\mathrm{Tris} / \mathrm{HCl}(\mathrm{pH} 8)$ and incubated for $5 \mathrm{~min}$ at $30^{\circ} \mathrm{C}$ in $0.2 \mathrm{~mm}$-dithiothreitol (DTT) and $0.12 \mathrm{~mm}-\mathrm{NADH}$ as substrate. Luteolin at different concentrations was added to the membrane suspension and the NADH oxidase activity was measured spectrophotometrically (Ravanel et al., 1982).

Luteolin analysis. Samples $(40 \mathrm{ml})$ of $R$. meliloti cultures growing in the presence of luteolin were taken at different time intervals and centrifuged at $5000 \mathrm{~g}$ for $30 \mathrm{~min}$ at $4{ }^{\circ} \mathrm{C}$. The bacterial pellet was

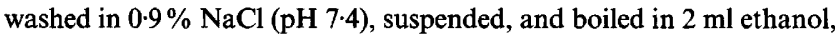
then $2 \mathrm{ml}$ chloroform was added. After a second centrifugation at $5000 \mathrm{~g}$ for $30 \mathrm{~min}$, the supernatant was collected, evaporated under a nitrogen stream and resuspended in $1 \mathrm{ml}$ ethanol. This extract was then analysed for luteolin content by TLC, spectrophotometry or HPLC. For the fractionation of membranes, the analyses were made from $500 \mathrm{ml}$ of bacterial culture containing luteolin.

For TLC, the solvent used was chloroform/acetone/methanol/acetic acid/water (10:4:2:2:1, by vol.; Trémolières \& Lepage, 1971). 
Luteolin gave a yellow spot in the first third of the chromatogram $\left(R_{F}=0 \cdot 72\right)$.

For spectrophotometric measurement, the absorbance of luteolin (purchased from Carl Roth) was measured in ethanol at $351 \mathrm{~nm}$ against the same bacterial extract which had not been treated with luteolin. The amount of luteolin was calculated from a standard curve obtained with standard solutions. The absorbance of quercetin and naringenin (purchased from Extrasynthese) were measured at $373 \mathrm{~nm}$ and at $288 \mathrm{~nm}$ respectively in ethanol.

HPLC analysis was performed using a method adapted from Peters et al. (1986). Using a C18 ODS column $(220 \times 4.6 \mathrm{~mm})$ a linear gradient was performed at $1 \mathrm{ml} \mathrm{min}^{-1}$ starting from methanol $(20 \%)$ and water $(80 \%)$ with acetic acid $(2 \%)$ to $100 \%(\mathrm{v} / \mathrm{v})$ methanol. Luteolin was eluted at about $20 \mathrm{~min}$ and read at $351 \mathrm{~nm}$; quercetin read at the same wavelength was eluted just before luteolin; naringenin eluted at $30 \mathrm{~min}$ was read at $280 \mathrm{~nm}$. For quantitative measurements, standard flavonoids were used as references.

\section{Results}

\section{Characteristics of luteolin absorption by whole bacteria}

We first verified that luteolin did not affect the growth of bacteria in TA medium. The kinetics of luteolin absorption by $R$. meliloti strain $\mathrm{Rm} 41$ was then followed at different concentrations of luteolin in the culture medium. Fig. 1 shows that the uptake of luteolin increased with increasing concentrations of the flavonoid in the medium. The luteolin absorption was rapid; when a bacterial culture was mixed with luteolin-containing medium, a high level of absorption was recorded immediately. It was verified that this rapid absorption did not result from contamination during the centrifugation of the bacterial pellet with the culture medium by

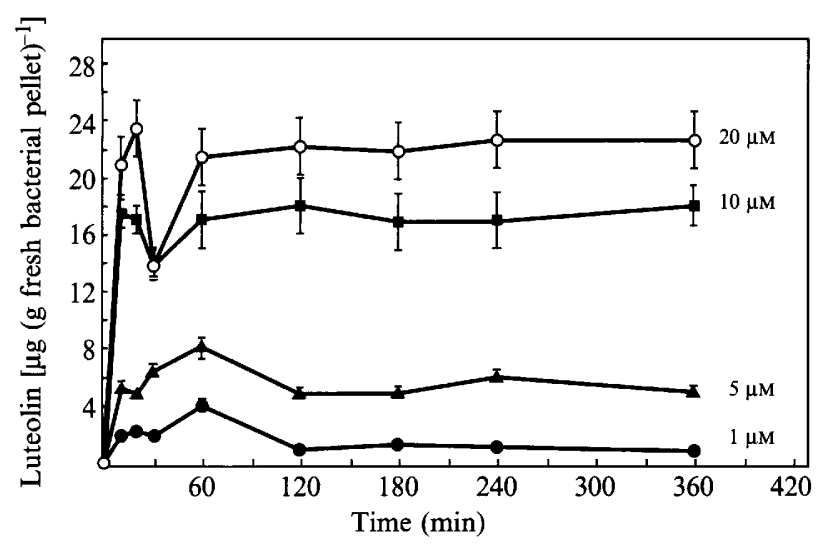

Fig. 1. Kinetics of luteolin absorption by $R$. meliloti strain Rm41. Bacteria were incubated in a medium containing different luteolin concentrations $(1 \mu \mathrm{M}, 5 \mu \mathrm{M}, 10 \mu \mathrm{M}$ and $20 \mu \mathrm{M})$ and for different times. In order to take into account the growth rate of the bacteria, luteolin was added $360,240,180,120,60,30,20$ and $10 \mathrm{~min}$ before the end of the experiment. Bacteria were pelleted and luteolin content was determined at the same culture OD for each time. Luteolin absorption is expressed in $\mu \mathrm{g}$ ( $\mathrm{g}$ fresh bacterial pellet $)^{-1}$. Values are means of five experiments $\pm \mathrm{SE}$. washing the pellet several times in $0.9 \% \mathrm{NaCl}$ without significant loss of luteolin. At 10 and $20 \mu \mathrm{M}$, the two highest concentrations of luteolin in the medium, a transitory decrease of the bacterial flavonoid content was observed after the first rapid incorporation step (Fig. 1). This leakage of luteolin was observable only for high concentrations of luteolin $(10 \mu \mathrm{M})$. The significance of this decrease is unknown. In further experiments, we always used luteolin at a concentration of $10 \mu \mathrm{M}$. When the concentration of luteolin was measured in the culture medium, only a very small decrease of this concentration (from 2.5 to $2.0 \mathrm{mg} \mathrm{m}^{-1}$ ) was observed at the beginning of the incubation, and after that it remained constant (data not shown). Under the conditions used, luteolin always remained in excess in the medium.

\section{Resorption of luteolin}

Bacteria incubated for $4 \mathrm{~h}$ in the presence of luteolin were pelleted, washed with $\mathrm{NaCl}(0.9 \%)$ and transferred into fresh medium without luteolin. Leakage of luteolin from the bacteria was observed immediately (Fig. 2) and only a low but significant amount of luteolin (about $10 \%$ of the original content) remained absorbed by the bacteria. After $10 \mathrm{~min}$, the bacterial luteolin content slowly increased for several hours, probably because newly formed bacteria incorporated the luteolin leaked out into the medium. This rapid leakage could be attributed to a partitioning effect between the aqueous phase of the medium (where ionized luteolin can be dissolved) and the lipid phase of the bacterial membrane (where luteolin in non-ionized form remains absorbed), as proposed by Recourt et al. (1989). In our conditions ( $9.5 \mathrm{mg}$ fresh bacteria per $\mathrm{ml}$ incubation medium), bacteria occupied less than $1 \%$ of the volume; in this case, the simple equilibrium process in a new medium devoid of luteolin would normally lead to a bacterial luteolin concentration ten times lower than that found in our experiment. Partitioning alone cannot explain such a result.

\section{Absorption of luteolin by other Gram-negative bacteria and absorption of other flavonoids by R. meliloti}

For all Gram-negative bacteria studied other than $R$. meliloti, a low rate of luteolin absorption was observed (Table 2). For A. tumefaciens and A. rhizogenes, $P$. syringae and $E$. coli, the absorption was about 10 -fold less than for $R$. meliloti. With $R$. leguminosarum biovar viciae, a Rhizobium species where the nod genes are not induced by luteolin but by other flavones, such as naringenin (Recourt et al., 1989), the absorption was also significantly lower than in $R$. meliloti. In this case, there 


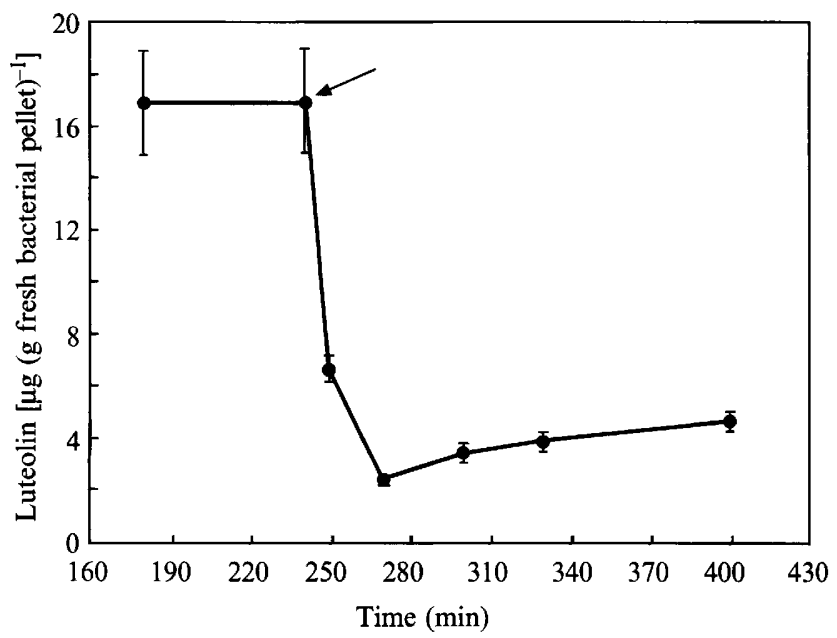

Fig. 2. Kinetics of luteolin resorption by $R$. meliloti strain Rm41. Bacteria were incubated with luteolin $(10 \mu \mathrm{M})$ for $4 \mathrm{~h}$, washed and then reincubated in a fresh medium without luteolin (arrow). Luteolin absorption is expressed as $\mu \mathrm{g}$ ( $\mathrm{g}$ fresh bacterial pellet $)^{-1}$. Values are means of five experiments $\pm \mathrm{SE}$.

\section{Table 2. Rate of luteolin absorption}

R. meliloti ( $\mathrm{Rm} 41)$, R. leguminosarum biovar viciae, A. rhizogenes, $A$. tumefaciens, $P$. syringae and $E$. coli were incubated for $4 \mathrm{~h}$ in a medium containing $10 \mu \mathrm{M}$-luteolin. Values are means of five experiments $\pm \mathrm{SE}$.

\begin{tabular}{lc}
\hline \hline & $\begin{array}{c}\text { Bacterial luteolin content } \\
{\left[\mu \mathrm{g}(\mathrm{g} \text { fresh bacterial pellet })^{-1}\right]}\end{array}$ \\
\hline R. meliloti $\mathrm{Rm} 41$ & $18 \cdot 8 \pm 1$ \\
R. leguminosarum biovar viciae & $10 \cdot 9 \pm 0 \cdot 6$ \\
A. rhizogenes & $4 \cdot 1 \pm 0 \cdot 4$ \\
A. tumefaciens & $0 \cdot 9 \pm 0 \cdot 2$ \\
$P$. syringae & $2 \cdot 2 \pm 0 \cdot 2$ \\
E. coli & $2 \cdot 2 \pm 0 \cdot 2$ \\
\hline \hline
\end{tabular}

Table 3. Rate of luteolin absorption by R. meliloti $(R m 4 I)$ and $R$. leguminosarum biovar viciae

Bacteria were incubated for $30 \mathrm{~s}, 10 \mathrm{~min}$ and $240 \mathrm{~min}$ with $10 \mathrm{~mm}$ luteolin. Values are means of five experiments $\pm \mathrm{SE}$.

\begin{tabular}{|c|c|c|c|}
\hline & \multicolumn{3}{|c|}{$\begin{array}{c}\text { Bacterial luteolin content } \\
{\left[\mu \mathrm{g}(\mathrm{g} \text { fresh bacterial pellet })^{-1}\right]}\end{array}$} \\
\hline & $30 \mathrm{~s}$ & $10 \mathrm{~min}$ & $240 \mathrm{~min}$ \\
\hline $\begin{array}{l}\text { R. meliloti } \\
\text { R. leguminosarum biovar viciae }\end{array}$ & $\begin{array}{l}26 \cdot 5 \pm 1 \\
13 \cdot 5 \pm 0 \cdot 5\end{array}$ & $\begin{array}{l}11 \cdot 4 \pm 0 \cdot 4 \\
10 \cdot 9 \pm 0 \cdot 3\end{array}$ & $\begin{array}{l}18 \cdot 8 \pm 1 \\
10 \cdot 9 \pm 0 \cdot 3\end{array}$ \\
\hline
\end{tabular}

was a rapid and weaker incorporation which always remained at the same level and did not exhibit kinetics similar to that of $R$. meliloti (Table 3 ). When $R$. meliloti was grown in the presence of naringenin or quercetin,
Table 4. Rate of flavonoid absorption by R. meliloti $(R m 4 I)$

Bacteria were incubated for $4 \mathrm{~h}$ with luteolin, naringenin or quercetin, each at a concentration of $10 \mu \mathrm{M}$. Values are means of five experiments $\pm \mathrm{SE}$.

\begin{tabular}{lc}
\hline \hline & Bacterial flavone content \\
Flavonoid & {$\left[\mu \mathrm{g}(\mathrm{g} \text { fresh bacterial pellet })^{-1}\right]$} \\
\hline Luteolin & $18 \cdot 8 \pm 1$ \\
Naringenin & $8 \cdot 3 \pm 0 \cdot 5$ \\
Quercetin & $7 \cdot 3 \pm 0.5$ \\
\hline \hline
\end{tabular}

Table 5. Rate of luteolin absorption by wild-type and mutant $R$. meliloti strains

Bacteria were incubated with $10 \mu \mathrm{M}$-luteolin for $4 \mathrm{~h}$. Strains: $\mathrm{Rm} 41$ and $\mathrm{Rm} 1021$ are wild-type isolates; $\mathrm{AK} 631$, exoB derivative of Rm41; EK1261, overexpresses the nod genes; AK1672, nodC; $\mathrm{A} 2105$, nodD1,D2,D3, ZB138, derivative of AK631 carrying deletion in the nod-nif region of the megaplasmid. Values are means of five experiments $\pm \mathrm{SE}$.

\begin{tabular}{lc}
\hline \hline Strain & $\begin{array}{c}\text { Bacterial luteolin content } \\
{\left[\mu \mathrm{g}(\mathrm{g} \text { fresh bacterial pellet) })^{-1}\right]}\end{array}$ \\
\hline Rm41 & $18 \cdot 8 \pm 1$ \\
Rm1021 & $18 \cdot 4 \pm 1$ \\
EK1261 & $24 \cdot 1 \pm 2$ \\
AK631 & $13 \cdot 7 \pm 1 \cdot 5$ \\
AK1672 & $14 \cdot 5 \pm 1 \cdot 4$ \\
A2105 & $9 \cdot 6 \pm 1$ \\
ZB138 & $5 \cdot 8 \pm 0 \cdot 6$ \\
\hline
\end{tabular}

which allow a normal rate of growth at the concentration used, but do not induce the expression of the nodulation genes in R. meliloti (Györgypal et al., 1991b), only weak absorption was observed (Table 4).

\section{Comparison of luteolin absorption between wild-type strains and mutants of $R$. meliloti}

Using wild-type and mutant $R$. meliloti strains, luteolin absorption was measured for $4 \mathrm{~h}$ at a luteolin concentration of $10 \mu \mathrm{M}$ for a starting bacterial $\mathrm{OD}_{540}$ of $0 \cdot 3$, increasing to a final OD of $0 \cdot 7$. As shown in Table 5, the exopolysaccharide-producing wild-type strains $\mathrm{Rm} 41$ and $\mathrm{Rm} 1021$ had high levels of absorption. In strain AK631, an exoB derivative of $\mathrm{Rm} 41$, the absorption was reduced to about $30 \%$ of that of Rm41. In AK1672, a nodC mutant derivative of AK631, the luteolin absorption did not differ from AK631, while in a nodD1D2D3 mutant (A2105) and in a derivative carrying a large deletion in the megaplasmid (ZB138), the absorption of luteolin was much lower. On the other hand, strain EK1261, which overexpresses the nod genes, showed a higher level of luteolin absorption than the 


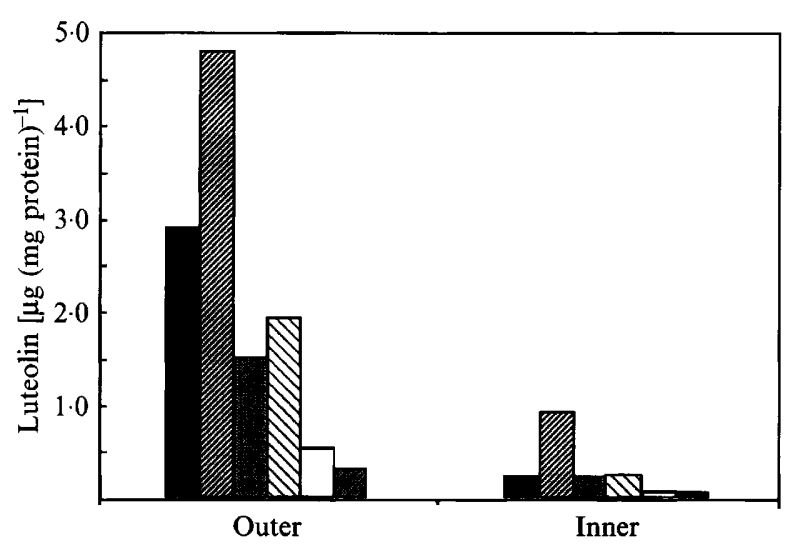

Fig. 3. Determination of the luteolin content in outer and inner membranes of different wild-type and mutant strains of $R$. meliloti after incubation for $8 \mathrm{~h}$ in $10 \mu \mathrm{M}$ luteolin-containing medium. Luteolin

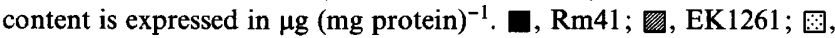
AK631; $\mathbb{}$, AK1672; $\square$, A2105; 圆, ZB138.

wild-type strain $\mathrm{Rm} 41$. These data indicate that several genes (exo and nod) influence (directly or indirectly) the overall level of luteolin absorption by $R$. meliloti.

\section{Comparison of luteolin incorporation in outer and inner membranes of the wild-type strain}

After incubation for different times in the presence of luteolin, bacteria were pelleted, then disrupted in the French press, and outer and inner membranes were isolated as previously described (Hubac et al., 1992). The luteolin content was determined by HPLC and spectrophotometric analysis. The luteolin content was also determined in the supernatant of the first centrifugation after the breakage of the cells. The luteolin found in the supernatant could represent both the cytoplasmic luteolin pool and the fraction of luteolin weakly attached to the external side of the bacterial envelope which could be lost during the disruption of the cells.

After $8 \mathrm{~h}$ of bacterial growth in the presence of luteolin $(10 \mu \mathrm{M})$, most of the bound flavonoids were found in the outer membrane, and only $10-20 \%$ was found in the inner membrane (Fig. 3). After short incubation times, most of the luteolin was found in the supernatants (Table $6)$. Then, the luteolin content decreased in the supernatant and increased progressively in the two membranes. The ratio of luteolin absorbed to the outer and inner membranes remained almost constant during the incubation period. These characteristics of luteolin binding were consistent with a two-step process: first, a rapid fixation on the external site of the bacterial envelope and then a slower accumulation in the membranes themselves and especially in the outer one. Nevertheless, it is difficult to be sure that the luteolin distribution found between isolated membranes repre- sents the true situation in the living bacteria and that no cross-contamination occurred during the isolation process.

\section{Luteolin incorporation in outer and inner membranes of} mutant strains

After $8 \mathrm{~h}$ growth of different mutant strains in the presence of luteolin $(10 \mu \mathrm{M})$, the bacteria were pelleted, disrupted in the French press, the outer and inner membranes were separated and the luteolin content was determined. As shown in Fig. 3, the luteolin content was reduced to about $30 \%$ in both the outer and inner membranes of AK631 not producing exopolysaccharides, but in those of the nodC mutant derivative of AK631 (AK1672) it was not further affected. In the two mutant strains which produce no NodD protein (A2105, ZB138) the luteolin accumulation was reduced in the two membranes, although a small amount of luteolin was always found in the inner membrane. The inner membrane was never completely devoid of luteolin in these two latter mutants; nevertheless contamination by the outer membrane cannot be completely ruled out. Strain EK1261, which overexpresses the nod genes, contained high amounts of luteolin in the two membranes.

The differences in luteolin content between the different strains were greater at the membrane level than when the luteolin content of whole cells was measured. This difference can be explained by the fact that luteolin found in the supernatant fraction was not taken into account when luteolin content in the isolated membranes was determined.

\section{Effect of luteolin on NADH oxidase activity}

Flavonoids can inhibit photosynthetic or respiratory electron transfer in chloroplasts or in plant mitochondria (Moreland \& Novitzky, 1988; Ravanel et al., 1982, 1990). Preferential accumulation of luteolin in the outer membrane might allow the protection of the respiratory chain located in the inner membrane against an excess of flavonoid. In order to test this possibility, we measured the effect of luteolin on NADH oxidase, one of the main enzymes of the respiratory chain.

When total membrane fractions of strain $\mathrm{Rm} 41$ were treated with luteolin, a significant inhibition of NADH oxidase activity was observed (Fig. $4 a$ ). The same result was obtained when isolated inner membranes containing NADH oxidase were treated with luteolin: $50 \mu \mathrm{M}-$ luteolin inhibited NADH oxidase activity by $65 \%$ and this activity was totally suppressed with luteolin at $100 \mu \mathrm{M}$ (Fig. $4 b$ ). No NADH oxidase activity was found in the outer membrane. 
Table 6. Repartition of luteolin in outer and inner membranes and in the supernatant fraction after different times of incubation of $R$. meliloti $(R m 41)$ in medium containing $10 \mu \mathrm{M}$-luteolin

Washed bacteria were resuspended in Tris/ $\mathrm{HCl}$, broken by passage through French press, then centrifuged at $130000 \mathrm{~g}$ for $2 \mathrm{~h}$. The luteolin content was determined in the supernatant. The membrane pellet was resuspended in $1 \mathrm{ml}$ Tris/ $\mathrm{HCl}$ and outer and inner membranes were separated on sucrose gradient. Luteolin content was then determined in the separated membranes.

\begin{tabular}{cccc}
\hline \hline & \multicolumn{3}{c}{ Luteolin absorbed $\left[\mu \mathrm{g}(\mathrm{mg} \text { protein })^{-1}\right]$} \\
\cline { 2 - 4 } Incubation time & Supernatant & Outer membrane & Inner membrane \\
\hline $10 \mathrm{~min}$ & 0.29 & 0.45 & 0.048 \\
$2 \mathrm{~h}$ & 0.21 & 1.07 & 0.090 \\
$4 \mathrm{~h}$ & 0.04 & 2.90 & 0.220 \\
\hline
\end{tabular}

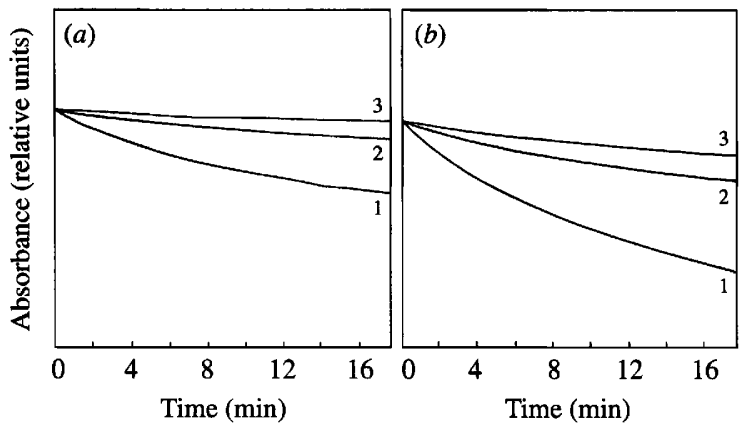

Fig. 4. Effect of luteolin on the activity of NADH oxidase. (a) Total membranes; $(b)$ inner membranes from $\mathrm{Rm} 41$ isolated by centrifugation $(130000 \mathrm{~g}, 2 \mathrm{~h})$ of the cells broken by French press. Membranes were fractionated on a discontinuous sucrose density gradient. Samples $(25 \mu \mathrm{g})$ of membrane protein were incubated at $30^{\circ} \mathrm{C}$ in Tris $(\mathrm{pH} 8.0)$, $0.2 \mathrm{~mm}$-DTT and $0.12 \mathrm{mM}-\mathrm{NADH}$ with or without luteolin: $1,0 \mu \mathrm{m} ; 2$, $50 \mu \mathrm{M} ; 3,100 \mu \mathrm{M}$. Oxidation of NADH was followed at $340 \mathrm{~nm}$ for $16 \mathrm{~min}$.

\section{Discussion}

This paper demonstrates that luteolin absorption by $R$. meliloti is a far more complex process than previously postulated. We demonstrated some species-specificity of luteolin absorption in that another Rhizobium species, $R$. leguminosarum biovar viciae, or other Gram-negative bacteria, Pseudomonas, Agrobacterium or E. coli do not incorporate this flavonoid at the same level. Moreover, two other flavonoids which do not induce the nodulation process in $R$. meliloti are poorly absorbed by this bacterium. The biochemical basis of this specificity remains unknown. Nevertheless it can be supposed that some specific sites for this binding may exist in $R$. melilot which are not found in the other bacteria.

The first step of luteolin absorption appears to be a rapid and reversible process of equilibrium of the flavonoids between the medium and the bacterial cell surface as previously suggested for the absorption of naringenin by $R$. leguminosarum biovar viciae (Recourt et al., 1989). The second step, allowing the accumulation of luteolin in the two membranes of Rhizobium, seems to be more progressive and we could not prove that this step is purely passive. Much work has to be done to establish the energetic basis of this accumulation. The binding of luteolin is only partly reversible since, after transfer of the bacteria into a medium without luteolin, a small but significant amount of the flavonoid remained firmly bound to the bacteria.

Studying absorption of naringenin to isolated membranes of $R$. leguminosarum biovar viciae in vitro, Recourt et al. (1989) reported that naringenin could be bound to the membrane only at acidic $\mathrm{pH}$ and, in this condition, the flavonoid accumulated exclusively in the inner membrane. Our studies on the absorption in vivo of luteolin by $R$. meliloti cells led to different observations. Accumulation of luteolin was detected principally in the outer membrane, while only low (but significant) amounts were bound to the inner membrane. According to previous reports (Ravanel et al., 1982, 1990; Moreland \& Novitzky, 1988) flavonoids can inhibit photosynthetic or respiratory electron transfer in plant chloroplasts or mitochondria. We found that luteolin at a concentration of around $50 \mu \mathrm{M}$ inhibited the activity of NADH oxidase, which is located in the inner membrane. According to our results, $R$. meliloti can incorporate around $20 \mu \mathrm{g}$ luteolin (g of fresh bacteria) ${ }^{-1}$. Thus the molar concentration of luteolin in the whole bacteria can be estimated as $70 \mu \mathrm{M}$. If we consider that most of this luteolin remained located in the membranes, that means that a concentration higher than $100 \mu \mathrm{M}$ (which is sufficient to totally inhibit NADH oxidase activity), can be found in this compartment. Based on these results, we can speculate that in $R$. meliloti there might be a specific system for the binding of large amounts of luteolin in the outer membrane, allowing the protection of the respiratory chain against this flavonoid.

Measurements of luteolin absorption by different mutant strains of $R$. meliloti have led to several conclusions. First, the incorporation into the exoB derivative of $\mathrm{Rm} 41$ was reduced to about $30 \%$. This strain is $\mathrm{Nod}^{+}$and was able to absorb luteolin and to incorporate it into the two membranes. The nodC mutant had a normal level of luteolin absorption. However, in the mutants where the three nodD genes are inactivated or deleted, the incorporation rate was significantly reduced. In contrast, the strain overexpressing the nod genes bound large amounts of luteolin.

The work of Horvath et al. (1987) and Spaink et al. (1989), and several further studies (Györgypal et al., $1991 a$; Kondorosi, 1992), suggested direct interaction 
between inducing compounds and the nodD gene product. Schlaman et al. (1989) presented a model for nod gene regulation based on the amphipathic NodD protein localized in the cytoplasmic membrane and its interaction with nod box DNA and flavonoids. From our results, it is difficult to firmly conclude that the NodD protein itself is the only site of binding for luteolin in the inner membrane. Luteolin was always found in the inner membrane of the triple nodD mutants and absorption by the outer membrane was also drastically reduced. This low level of absorption might be due to insufficient stabilization of luteolin in the bacterial membrane when NodD protein is lacking.

It is probable that only a small fraction of the luteolin pool interacts with the NodD protein. At present, nothing is known about the kinetic parameters and the stability of this interaction. It is likely that a relatively high level of luteolin per bacterium might be necessary to maintain the activity of the nod regulon. For the better understanding of the interactions between luteolin and NodD more suitable methods have to be developed which could allow the measurement of very small amounts of luteolin and also to determine the cytosolic luteolin content.

We thank Dr E. Kondorosi for construction of bacterial strains used in this work. We wish also to acknowledge C. Deforeit for typing, and J. C. Barbet and A. Bennardo-Connan for helpful technical assistance.

\section{References}

Alt-Moerbe, J., Kuehlmann, H. \& Schroeder, J. (1989). Differences in induction of $\mathrm{Ti}$ plasmid virulence genes virG and virD and continued control of virD expression by four external factors. Molecular Plant-Microbe Interactions 2, 301-308.

APPLEYARD, R. K. (1954). Segregation of new lysogenic types during growth of a doubly lysogenic strain derived from Escherichia coli K12. Genetics 39, 440-452.

Banfalvi, Z., Sakanyan, V., Koncz, C., Kiss, A., Dusha, I. \& KONDOROSI, A. (1981). Location of nodulation and nitrogen fixation genes on a high molecular weight plasmid $R$. meliloti. Molecular and General Genetics 184, 318-325.

BERINGER, J. E. (1974). R factor transfer in Rhizobium leguminosarum. Journal of General Microbiology 84, 188-189.

BRADFORD, M. M. (1976). A rapid and sensitive method for the quantitation of microgram quantities of protein utilizing the principle of protein-dye binding. Analytical Biochemistry 72, 248-254.

GYÖRGYPAL, Z., Kiss, G. B. \& KonDOROSI, A. (1991 a). Transduction of plant signal molecules by the Rhizobium NodD proteins. BioEssays $13,575-581$.

GyörgYPAL, Z., Kondorosi, E. \& KondoRosi, A. (1991 b). Diverse signal sensitivity of NodD protein homologs from narrow and broad host range rhizobia. Molecular Plant-Microbe Interactions 4, 356-364.

Hartwig, U. A., Joseph, C. M. \& Phillips, D. A. (1991). Flavonoids released naturally from alfalfa seeds enhance growth rate of Rhizobium meliloti. Plant Physiology 95, 797-803.

Honma, M. A., Asomaning, M. \& Ausubel, F. M. (1990). Rhizobium meliloti nodD mediates host-specific activation of nodABC. Journal of Bacteriology 172, 901-911.

Horvath, B., Bachem, C., Schell, J. \& Kondorosi, A. (1987). Hostspecific regulation of nodulation genes in Rhizobium is mediated by a plant signal interacting with the nodD gene product. $E M B O$ Journal 6, 841-848.

Hubac, C., Guerrier, D., Ferran, J., TrÉmolières, A. \& Kondorosi, A. (1992). Lipid and protein composition of outer and inner membranes in wild type strains and nod mutants of Rhizobium meliloti. Journal of General Microbiology 138, 1973-1981.

Josey, D. P., Beynon, J. L., Johnston, A. W. B. \& Beringer, J. E. (1979). Strain identification of Rhizobium using intrinsic antibiotic resistance. Journal of Applied Bacteriology 46, 343-350.

KoNDOROSI, A. (1992). Regulation of nodulation genes in rhizobia. In Molecular Signals in Plant-Microbe Communications, pp. 325-340. Edited by D. P. S. Verma. Boca Raton: CRC Press.

Kondorosi, A., Svab, Z., Kiss, G. B. \& Dixon, R. A. (1977). Ammonia assimilation and nitrogen fixation in Rhizobium meliloti. Molecular and General Genetics 151, 221-226.

Kondorosi, E., Banfalvi, Z. \& Kondorosi, A. (1984). Physical and genetic analysis of a symbiotic region of $R$. meliloti: identification of nodulation genes. Molecular and General Genetics 193, 445-452.

Kondorosi, E., Gyuris, J., Schmidt, J., John, M., DudA, E., HoffmanN, B., Schell, J. \& Kondorosi, A. (1989). Positive and negative control of nod gene expression in Rhizobium meliloti is required for optimal nodulation. EMBO Journal 5, 1331-1340.

DE MAAGD, R. \& LUGTENBERG, B. (1986). Fractionation of Rhizobium leguminosarum cells into outer membrane, cytoplasmic membrane, periplasmic and cytoplasmic components. Journal of Bacteriology $167,1083-1085$

Meade, H. M., Long, S. R., Ruvkun, G. B., Brown, S. E. \& Ausubel, F. M. (1982). Physical and genetic characterization of symbiotic and auxotrophic mutants of Rhizobium meliloti induced by transposon Tn5 mutagenesis. Journal of Bacteriology 149, 114-122.

MENG, Z. \& WANG, X. (1987). Laboratory studies on the factors affecting toxigenicity of Flavobacterium farinofermentas. Chinese Journal of Preventive Medicine 21, 80-92.

Michel, M. F., Brasileiro, A. C. M., Depierreux, C., Otten, L., Delmotte, F. \& Jouanin, L. (1990). Identification of different Agrobacterium strains isolated from the same forest nursery. Applied and Environmental Microbiology 56, 3537-3545.

MoReland, D. E. \& Novitzky, W. P. (1988). Interference by flavone and flavonols with chloroplast-mediated electron transport and phosphorylation. Phytochemistry 27, 3359-3366.

Peters, N. K., Frost, J. W. \& Long, S. R. (1986). A plant flavone, luteolin, induces expression of Rhizobium meliloti nodulation genes. Science 233, 977-980.

Petit, A., David, C., Dahl, A., Ellis, J. C. \& GuYon, P. (1983). Further extension of the opine concept: plasmids in Agrobacterium rhizogenes cooperate for opine degradation. Molecular and Genetical Genetics 190, 204-214.

PHILliPs, D. A. (1992). Flavonoids: plant signals to soil microbes. Recent Advances in Phytochemistry 26, 201-231.

Ravanel, P., Tissut, M. \& Douce, R. (1982). Uncoupling activities of chalcones and dihydrochalcones on isolated mitochondria from potato tubers and mung bean hypocotyls. Phytochemistry 21, 2845-2850.

Ravanel, P., Creuzet, S. \& Tissut, M. (1990). Inhibitory effect of hydroxyflavones on the exogenous NADH dehydrogenase of plant mitochondrial inner membranes. Phytochemistry 29, 441-445.

Recourt, K., Van Brussel, A. A. H., Driessen, A. J. M. \& LUGTENBERG, B. J. J. (1989). Accumulation of nod gene inducer, the flavonoid naringenin, in the cytoplasmic membrane of Rhizobium leguminosarum biovar viciae is caused by the $\mathrm{pH}$-dependent hydrophobicity of naringenin. Journal of Bacteriology 171, 4370-4377.

Schlaman, H. R. M., Spaink, H. P., OKKer, R. J. H. \& Lugtenberg, B. J. J. (1989). Subcellular localization of the nodD gene product in Rhizobium leguminosarum. Journal of Bacteriology 171, 4686-4693.

SCHMIT, J. (1991). Races of Pseudomonas syringae pv. pisi. Occurrence in France and host specificity towards winter and spring cultivars of protein peas. In Pseudomonas syringae pathovars, Proceedings of the 4th International Work Group on Pseudomonas syringae pathovars, Florence, Italy, 10-13 June 1991, pp. 256-262.

Schultze, M., Quiclet-Sire, J. E., Kondorosi, E., Virelizier, H., GlushKa, J. N., Endre, G., Gero, S. D. \& Kondorosi, A. (1992). Rhizobium meliloti produces a family of sulfated lipooligosaccharides 
exhibiting different degrees of plant host specificity. Proceedings of the National Academy of Sciences of the United States of America 89, 192-196.

Spaink, H. P., OkKer, R. J. H., WiJfFelman, C. A., Tak, T., Goosen De Roo, T. T., Pees, E., Van Brussel, A. A. N. \& Lugtenderg, B. J. J. (1989). Symbiotic properties of rhizobia containing a flavonoid-independent hybrid nodD product. Journal of Bacteriology 171, 4045-4053.
TrÉmolières, A. \& LePaGe, M. (1971). Changes in lipid composition during greening of etiolated pea seedling. Plant Physiology 47, 329-334.

ZaAt, S. J., Wijffelman, C. A., Mulders, I. H. H., Van Brussel, A. A. N. \& LugtenberG, B. J. J. (1988). Root exudates of various host plants of Rhizobium leguminosarum contain different sets of inducers of Rhizobium nodulation genes. Plant Physiology 86, $1298-1303$ 